\title{
Scenario of consumer awareness among rural women of Ludhiana district and suggestions for their empowerment
}

\author{
SURINDERJIT KAUR AND HARINDER KAUR SAGGU
}

Received: 14.05.2014; Revised: 03.10.2014; Accepted: 17.10.2014

See end of the paper for authors' affiliations SURINDERJIT KAUR

Department of Family Resource Management, College of Home Science, Punjab Agricultural University, LUDHIANA (PUNJAB) INDIA

Email: sjk2961@ @ rediffmail.com
ABSTRACT : The present investigation was carried out to know the awareness of rural women regarding labels on packed food and textile items, quality assurance marks and consumer protection rights. The study was conducted on 120 rural women from four villages of Ludhiana district. Purposive sampling technique was used for sample selection and data were collected through an interview schedule. The results indicated that majority of the respondents had no knowledge about care symbols on textile goods, nearly $1 / 3^{\text {rd }}$ of respondents looked for Maximum Retail Price (MRP), manufacturing date and expiry date while purchasing packed food items. Almost all the respondents never looked for other details on labels. More than 90.00 per cent of respondents were unaware of Agmark, FPO, ISO and ECO mark, whereas more than 80.00 per cent of women were aware of ISI and Woolmark, but all of them were unable to distinguish between original clone ISI mark. Upto or less than five per cent of respondents had knowledge about Consumer Protection Rights and Act. So, there is a strong need to create consumer awareness among rural women through extension training programmes, consumer clubs and electronic media to avoid exploitation of rural consumers.

KEY WORDS: Awareness, Consumer, Care labels

口 HOW TO CITE THIS PAPER : Kaur, Surinderjit and Saggu, Harinder Kaur (2014). Scenario of consumer awareness among rural women of Ludhiana district and suggestions for their empowerment. Asian J. Home Sci., 9 (2) : 465-469. 